九州大学学術情報リポジトリ

Kyushu University Institutional Repository

\title{
Biosorption of Chromium (VI) Ions using Sustainable Eggshell Impregnated Pandanus amaryllifolius Roxb. Biosorbent
}

\section{N. Y. Yahya}

Faculty of Civil Engineering Technology, Universiti Malaysia Pahang, Lebuhraya Tun Razak

\section{J.X. Chan}

School of Chemical and Energy Engineering, Faculty of Engineering, Universiti Teknologi Malaysia

\section{N. Ngadi}

School of Chemical and Energy Engineering, Faculty of Engineering, Universiti Teknologi Malaysia

https://doi.org/10.5109/4372271

出版情報 : Evergreen. 8 (1)，pp.146-155，2021-03. Transdisciplinary Research and Education Center for Green Technologies, Kyushu University

バージョン :

権利関係 : 


\title{
Biosorption of Chromium (VI) Ions using Sustainable Eggshell Impregnated Pandanus amaryllifolius Roxb. Biosorbent
}

\author{
N.Y. Yahya ${ }^{1 *}$, J.X. Chan ${ }^{2}$, N. Ngadi ${ }^{*}$ \\ ${ }^{1}$ Faculty of Civil Engineering Technology, Universiti Malaysia Pahang, Lebuhraya Tun Razak, \\ 26300 Gambang, Kuantan, Pahang, Malaysia \\ ${ }^{2}$ School of Chemical and Energy Engineering, Faculty of Engineering, Universiti Teknologi Malaysia, \\ 81310 UTM Skudai, Johor, Malaysia
}

*Corresponding Author's email: yahida@ump.edu.my, norzita@cheme.utm.my

(Received November 27, 2020; Revised March 19, 2021; accepted March 23, 2021).

\begin{abstract}
Currently, wastewater containing heavy metals treatment has been included as a significant topic for research. This is due to the effluent that is concentrated with a toxic and hazardous content which needs for a proper treatment as to reduce the environmental impacts before it can be released as an effluent. Therefore, biosorption by waste material was proposed in this study as a treatment method for this type of wastewater. The objective is focus on the comparison of the characteristics and performance of raw eggshell waste biosorbent with prepared hybrid eggshellpandan biosorbent on the removal of $\mathrm{Cr}$ (VI) ions in aqueous solution. From the study, it showed that the prepared hybrid biosorbent perform higher percentage in the removal of $\mathrm{Cr}$ (VI) ions in aqueous solution compare to the raw eggshell waste with its optimum condition at $140 \mathrm{~min}$ of contact time, $0.5 \mathrm{~g}$ of biosorbent dosage at $50^{\circ} \mathrm{C}$ and $\mathrm{pH} 4$ in $0.8 \mathrm{mg} / \mathrm{L}$ of solution concentration. On the other hands, the optimum conditions for the raw eggshell waste biosorbent to achieve its highest percentage removal of $\mathrm{Cr}$ (VI) ions in aqueous solution is 140 mins of contact time, $0.5 \mathrm{~g}$ of biosorbent dosage in room temperature at $\mathrm{pH} 5$ in $0.8 \mathrm{mg} / \mathrm{L}$ of solution concentration. The kinetic study revealed that the adsorption model of this study follows the pseudo-second-order kinetic model of Legergren with positive value of enthalpy $(16.68 \mathrm{~kJ} / \mathrm{mol})$ and entropy change $(0.0473 \mathrm{~kJ} / \mathrm{mol})$. In addition, hybrid eggshell-pandan biosorbent has a potential to become a candidate of biosorbent to the removal of $\mathrm{Cr}(\mathrm{VI})$ ions in wastewater.
\end{abstract}

Keywords: eggshell waste; pandan leaves; adsorption; $\mathrm{Cr}(\mathrm{VI})$ ion; biosorbent

\section{Introduction and Background}

Presence of heavy metals as pollutants in water source is the cause of global concern due to the increasing of global demand everyday ${ }^{1,2,3,4)}$. In order to achieve the standards and regulations, effluents are treated before discharging into water bodies. With the advent of biosorbents, people started to use waste materials such as charcoal and carrot as potential adsorbents to remove organic and inorganic substance in wastewater ${ }^{5,6)}$.

$\mathrm{Cr}$ (VI) ion is amongst hazardous pollutants in aquatic environment due to its strong oxidizing capacity and highly dissolved ion in water ${ }^{7)}$. It can exist as $\mathrm{Cr}_{2} \mathrm{O}_{7}{ }^{2-}$, $\mathrm{CrO}_{4}{ }^{2-}$, and $\mathrm{HCrO}^{4-}$ ions in water ${ }^{8)}$. The consumption of egg as a has tripled in the past 40 years ${ }^{9}$. The high consumption of eggshells indicated the increasing disposal of eggshell. Thus, chicken eggshell is choosing to be used as innovative adsorbent to remove chromium ions from aqueous solution in water treatment plant. To increase the uptake capacity of eggshell as adsorbent, eggshell will be hybridized with extracted pandan leaves.

\section{Methodology}

\subsection{Materials}

Fresh pandan leaves (Pandanus amaryllifolius Roxb.) was obtained near local residence at Taman Universiti, Skudai, Johor, Malaysia. Material and chemicals being used in this study were raw eggshell waste, ethanol $\left(\mathrm{C}_{2} \mathrm{H}_{6} \mathrm{O}\right.$, 95\% v/v), potassium dichromate, sodium hydroxide $(\mathrm{NaOH})$, hydrochloric acid $(\mathrm{HCl})$, distilled water and deionized water. Chemicals was acquired from Sigma Aldrich (Analytical grade) and used as received without prior treatment.

\subsection{Preparation of biosorbent}

Raw eggshells waste was collected and washed with deionized water. It was air-dried and incubated in hot air oven at $40{ }^{\circ} \mathrm{C}$ for one day. Then, it was grinded into powder and sieved to obtain $106 \mu \mathrm{m}$ particle size. The prepared powder eggshell was kept in an airtight container. 
Pandan leaves at approximately $200 \mathrm{~g}$ was cleaned, cut into smaller pieces (approximately $3 \mathrm{~cm}$ ) and immediately dried in an oven at $105{ }^{\circ} \mathrm{C}$ for $24 \mathrm{~h}$. Then, the pandan leaves sample was grinded into $150 \mu$. Ethanol was used as solvent for solvent extraction process for $24 \mathrm{~h}$. The permeate liquid obtained was heated at $80{ }^{\circ} \mathrm{C}$ to remove the remaining ethanol. $0.1 \mathrm{~g}$ of eggshell powder was dissolved in $50 \mathrm{~mL}$ of extracted pandan oil at room temperature. After $24 \mathrm{~h}$, the mixture was filtered and washed with deionized water to establish neutral $\mathrm{pH}$. The, it was dried in oven at $110{ }^{\circ} \mathrm{C}$ until constant weight is obtained. The dried final product was the modified eggshell-pandan sorbent.

\subsection{Characterization}

Functional group found in raw eggshell waste, and hybrid eggshell-pandan biosorbent was determined using Fourier Transform Infrared (FTIR). The samples were recorded with spectral region of $400 \mathrm{~cm}^{-1}$ to $4000 \mathrm{~cm}^{-1}$ and resolution at $2 \mathrm{~cm}^{-1}$. At the same time, Scanning Electron Microscopy (SEM) was used to analyse the surface morphologies. Raw eggshell waste and hybrid biosorbent was being characterized in term of specific surface area via Brunauer, Emmett and Teller (BET). Single point nitrogen adsorption-desorption isotherm at $403 \mathrm{~K}\left(130^{\circ} \mathrm{C}\right)$ was introduced.

\subsection{Adsorption study}

\subsubsection{Effect of reaction time}

To investigate the effect of reaction time on the removal capacity of modified sorbent, parameters other than reaction time will be fixed. For this set of experiment, initial concentration of solution was $0.8 \mathrm{mg} / \mathrm{L}$, with $0.1 \mathrm{~g}$ of biosorbent dosage, at $\mathrm{pH} 4$ and room temperature. Then, the mixture was stirred continuously and the sample was collected for every 20 minutes until equilibrium achieved. Concentration of $\mathrm{Cr}$ (VI) ions was determined using COD meter and Multiparameter Photometer. The efficiency of the adsorption (\%) was calculated using equation (1).

$$
\mathrm{E} \%=\frac{\mathrm{c}_{\mathrm{i}}-\mathrm{c}_{\mathrm{e}}}{\mathrm{c}_{\mathrm{i}}} \times 100
$$

where $c_{i}$ is the initial equilibrium concentration of $\mathrm{Cr}$ (VI) $(\mathrm{mg} / \mathrm{L})$ in wastewater and $\mathrm{c}_{\mathrm{e}}$ is the final equilibrium concentration of $\mathrm{Cr}(\mathrm{VI})(\mathrm{mg} / \mathrm{L})$ in wastewater.

\subsubsection{Effect of biosorbent dosage}

$0.1 \mathrm{~g}$ of biosorbent was mixed with $50 \mathrm{~mL}$ of $0.8 \mathrm{mg} / \mathrm{L}$ of $\mathrm{Cr}$ (VI) ions solution at $\mathrm{pH} 4$ and room temperature. The sorption process was left stirring until the equilibrium time and collected to be examined. The experiment was repeated using $0.3 \mathrm{~g}, 0.5 \mathrm{~g}$, and $1 \mathrm{~g}$. The hybrid eggshellpandan biosorbent dosage with the greatest removal capacity was used for the following sets of experiment.

\subsubsection{Effect of temperature}

Optimum biosorbent dosage was mixed into $50 \mathrm{~mL}$ of $0.8 \mathrm{mg} / \mathrm{L}$ of $\mathrm{Cr}$ (VI) ions solution. The condition was set at $\mathrm{pH} 4$ and room temperature. The mixture was left stirring until it reached the equilibrium time and then was collected and analysed. The experiment being repeated using different temperature of solution as $40{ }^{\circ} \mathrm{C}, 50{ }^{\circ} \mathrm{C}$, $60{ }^{\circ} \mathrm{C}$ and $70{ }^{\circ} \mathrm{C}$. The temperature that showed the highest efficiency in removing heavy metal was used in following experiments.

\subsubsection{Effect of $\mathrm{pH}$}

Optimum biosorbent dosage was mixed into $50 \mathrm{~mL}$ of $0.8 \mathrm{mg} / \mathrm{L}$ of $\mathrm{Cr}$ (VI) ions solution at $\mathrm{pH} 4$ and optimum temperature. The mixture was left stirring until it reached the equilibrium time and then was collected and analysed. The experiment was repeated using different $\mathrm{pH}$ of solution as $5,6,7$ and 8 . The $\mathrm{pH}$ of the aqueous solution with the highest percentage of $\mathrm{Cr}$ (VI) removal was used for the following experiments.

\subsubsection{Effect of initial ion concentration}

Experiment was conducted as optimum amount of biosorbent dosage at optimum $\mathrm{pH}$ and temperature. Optimum dosage of hybrid sorbent was added into $50 \mathrm{~mL}$ of $0.8 \mathrm{mg} / \mathrm{L} \mathrm{Cr}$ (VI) ions solution. The sorption process was left stirring until the equilibrium time. The final sample was collected after equilibrium time and analysed by COD meter and Multiparameter Photometer. The experiment was repeated using $1 \mathrm{mg} / \mathrm{L}, 2 \mathrm{mg} / \mathrm{L}, 4 \mathrm{mg} / \mathrm{L}$, and $8 \mathrm{mg} / \mathrm{L}$. The initial concentration with the highest percentage of removal efficiency was obtained.

\subsection{Kinetic study}

Adsorption kinetics experiment was performed by contacting $50 \mathrm{~mL}$ of $\mathrm{Cr}(\mathrm{VI})$ solution at concentrations 0.8 $\mathrm{mg} / \mathrm{L}$ and with $0.1 \mathrm{~g}$ of hybrid eggshell-pandan sorbent and $\mathrm{pH} 4$ in beaker at room temperature. At each time intervals, the samples were taken and analyzed using COD meter and Multiparameter Photometer (Hanna Instrument-Model HI83099).

\subsubsection{Pseudo-first-order and pseudo-second-order kinetic model of lagergren}

Pseudo first-order model of Lagergren is established based on the theory where the rate of change of adsorbed analytes with time is proportional to the difference in equilibrium biosorption capacity and the adsorbed amount ${ }^{10)}$. Equation of pseudo-first-order kinetic model of Lagergren can be expressed as:

$$
\ln \left(\mathrm{q}_{\mathrm{e}}-\mathrm{q}_{\mathrm{t}}\right)=\ln \mathrm{q}_{\mathrm{e}}-\mathrm{k}_{1} \mathrm{t}
$$

where $\mathrm{q}_{\mathrm{e}}$ and $\mathrm{q}_{\mathrm{t}}$ are the amounts of adsorbate $(\mathrm{mg} / \mathrm{g})$ at equilibrium and at time $\mathrm{t}(\mathrm{min})$, respectively. while $\mathrm{k}_{1}$ is the rate constant of pseudo-first-order adsorption $\left(\mathrm{min}^{-1}\right)$. 
For pseudo-second-order kinetic model of Lagergren, it can be applied with the theory that the rate-limiting step comprises of chemisorption ${ }^{11)}$. It can be represented as:

$$
\mathrm{t} / \mathrm{q}_{\mathrm{t}}=1 / \mathrm{k}_{2} \mathrm{q}_{\rho}^{2}+\mathrm{t} / \mathrm{q}_{\rho}
$$

where $\mathrm{q}_{\mathrm{e}}$ and $\mathrm{q}_{\mathrm{t}}$ are the amounts of adsorbate $(\mathrm{mg} / \mathrm{g})$ at equilibrium and at time $t(\mathrm{~min})$, respectively. While $k_{2}$ is the rate constant of pseudo-second-order adsorption ( $\mathrm{min}^{-}$ $1)$.

\subsubsection{Intraparticle diffusion model}

Usually the adsorbates species is transported from the bulk solution into solid phase through intraparticle diffusion process. It is expressed as follow:

$$
\mathrm{q}_{\mathrm{t}}=\mathrm{K}_{\text {diff }} \mathrm{t}^{1 / 2}+\mathrm{C}
$$

where $\mathrm{C}(\mathrm{mg} / \mathrm{g})$ is the intercept and $\mathrm{K}_{\mathrm{diff}}$ is the intraparticle diffusion rate constant $\left(\mathrm{mg} / \mathrm{gmin}^{1 / 2}\right)$. The $\mathrm{q}_{\mathrm{t}}$ is a linearity correlation of $\mathrm{t}^{1 / 2}$ and rate constant $\mathrm{K}_{\text {diff }}$ from the slope of regression line. The linearity of the plot indicates the applicability of the experimental data as the intraparticle diffusion model. In this model, three linear regions are found connected the bulk diffusion, intraparticle diffusion and adsorption at active site ${ }^{11)}$.

\subsection{Adsorption isotherm model}

Biosorption properties and equilibrium data obtained from experiment will be applied into the isotherm models to describe the interaction between the adsorbate and the adsorbent. Langmuir isotherm can be expressed as:

$$
\mathrm{C}_{\mathrm{e}} / \mathrm{q}_{\mathrm{e}}=\mathrm{C}_{\mathrm{e}} / \mathrm{q}_{\mathrm{m}}+1 /\left(\mathrm{q}_{\mathrm{m}} \mathrm{b}\right)
$$

where qe is the amount of ion adsorbed (mg/g), $\mathrm{C}_{\mathrm{e}}$ is the equilibrium concentration of the adsorbate $(\mathrm{mg} / \mathrm{L})$, while $\mathrm{q}_{\mathrm{m}}(\mathrm{mg} / \mathrm{g})$ is the maximum adsorption capacity and $\mathrm{b}$ are Langmuir constants ${ }^{12}$. Then, Freundlich isotherm described that adsorption occurs on heterogeneous surfaces and can be represented as:

$$
\log q_{e}=\frac{1}{n} \log C_{e}+\log K_{f}
$$

where qe is the amount adsorbed at equilibrium $(\mathrm{mg} / \mathrm{g}), \mathrm{K}_{\mathrm{f}}$ is the Freundlich constant, $1 / \mathrm{n}$ is the heterogeneity factor which is related to the capacity and intensity of the adsorption, and $\mathrm{C}_{\mathrm{e}}$ is the equilibrium concentration $(\mathrm{mg} / \mathrm{L})^{13)}$. While for Temkin isotherm, it is established based on the assumption that the heat of adsorption is inversely proportional to the coverage of adsorbent due to the interaction between adsorbent and adsorbate and expressed as:

$$
\begin{aligned}
\mathrm{q}_{\mathrm{e}}=\frac{\mathrm{RT}}{\mathrm{b}} \ln (\mathrm{A})+ & \frac{\mathrm{RT}}{\mathrm{b}} \ln \mathrm{C}_{\mathrm{e}} \\
& =\mathrm{B} \ln (\mathrm{A})+\mathrm{B} \ln \mathrm{C}_{\mathrm{e}}
\end{aligned}
$$

where $\mathrm{B}=\mathrm{RT} / \mathrm{b}$ is a constant related to heat sorption $(\mathrm{J} / \mathrm{mol})$ obtained from the graph $\mathrm{q}_{\mathrm{e}}$ versus $\ln \mathrm{C}_{\mathrm{e}}$. A is Temkin isotherm equilibrium binding constant $(\mathrm{L} / \mathrm{g}), \mathrm{b}$ is Temkin isotherm constant, $\mathrm{R}$ is the universal gas constant $(8.314 \mathrm{~J} / \mathrm{mol} \mathrm{K})$ and $\mathrm{C}_{\mathrm{e}}$ is the equilibrium concentration $(\mathrm{mg} / \mathrm{L})^{12)}$.

\subsection{Thermodynamic studies}

The thermodynamic parameters can be calculated using equations below:

$$
\Delta \mathrm{G}^{0}=\Delta \mathrm{H}^{0}-\mathrm{T} \Delta \mathrm{S}^{0}
$$

$$
\Delta \mathrm{G}^{0}=-\mathrm{RT} \ln \left(\mathrm{K}_{\mathrm{d}}\right)
$$

where qe is the adsorption capacity at equilibrium. $\Delta \mathrm{G}^{\circ}$ is the standard Gibbs free energy change for the adsorption process $(\mathrm{J} / \mathrm{mol})$; $\mathrm{R}$ the universal gas constant $(8.314 \mathrm{~J} / \mathrm{mol} \mathrm{K})$, while $\mathrm{T}$ is the absolute solution temperature $(\mathrm{K})^{14)}$.

\section{Results and Discussion}

\subsection{Characterization}

\subsubsection{FTIR spectroscopy analysis}

The results of Fourier Transform Infrared (FTIR) study for raw eggshell waste and hybrid eggshell-pandan biosorbent is shown in Fig. 1 (a) and (b).

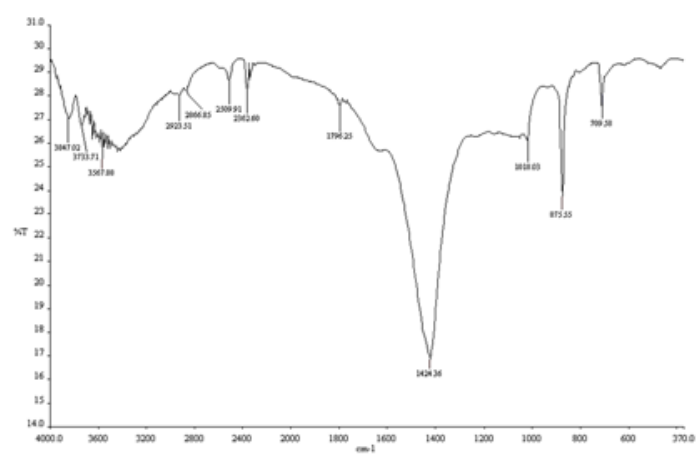

(a)

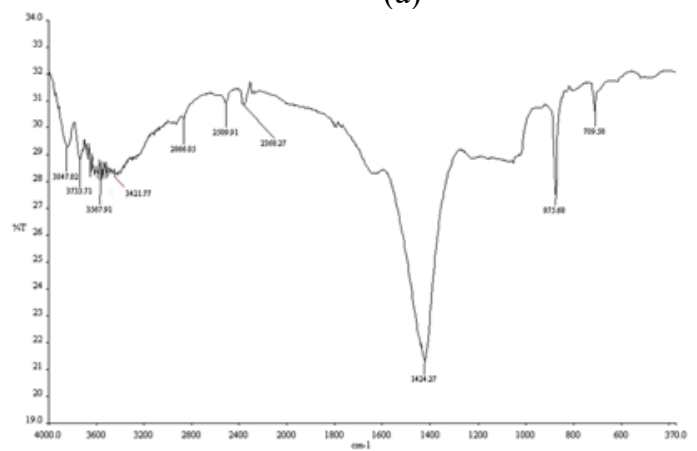

(b)

Fig. 1: IR spectrum of (a) raw eggshell waste and (b) hybrid 
eggshell-pandan biosorbents.

For raw eggshell powder, the adsorption peaks of $\mathrm{CO}_{3}{ }^{2-}$ is observed at $1796.25,1018.03,875.55$ and $709.58 \mathrm{~cm}^{-1}$ which indicated the stretching and bending of $\mathrm{C}=\mathrm{O}$. The band exhibited at 1424.36 and $2362.6 \mathrm{~cm}^{-1}$ is corresponded to the $\mathrm{C}=\mathrm{O}$ stretching vibration which indicates that calcite as the fundamental constituent of the eggshell ${ }^{15}$. In the high wavelength region, the most intensive peak is at around $3500 \mathrm{~cm}^{-1}$ followed by 3567.88 $\mathrm{cm}^{-1}$ which then corresponds to the bending and stretching mode of $\mathrm{O}-\mathrm{H}$ and $\mathrm{N}-\mathrm{H}$ groups.

Compared to the IR spectrum of the raw eggshell, the peaks at 1018.03, 1796.25 and $2923.51 \mathrm{~cm}^{-1}$ missing in hybrid sorbent because the 2-AP compound attached on the sorbent surface covered some of the component. The additional peak appears in the IR spectrum of hybrid eggshell-pandan sorbent at $3421.77 \mathrm{~cm}^{-1}$ represented the secondary amine in the 2-AP compound.

\subsubsection{SEM analysis}

SEM analysis shows the surface morphologies of the wall of the biosorbents. Fig. 2 (a) and (b) illustrates the SEM photography of the raw eggshell sorbent and the hybrid eggshell-pandan sorbent respectively both in powder form.

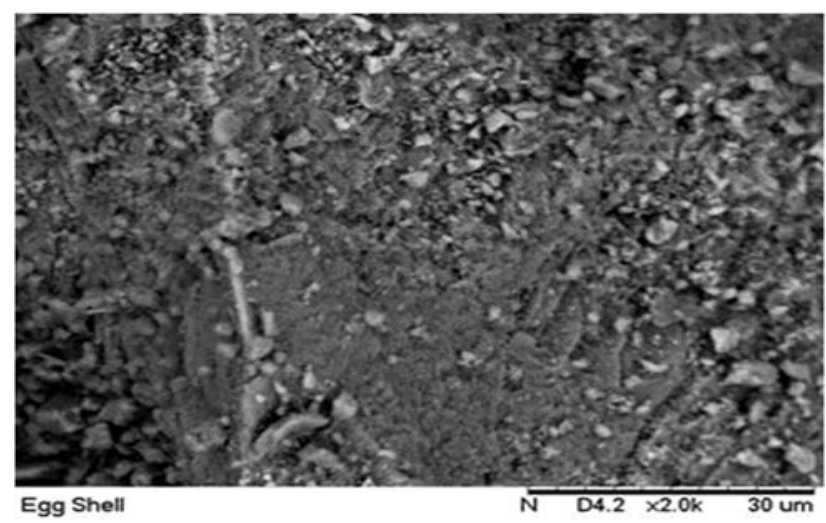

(a)

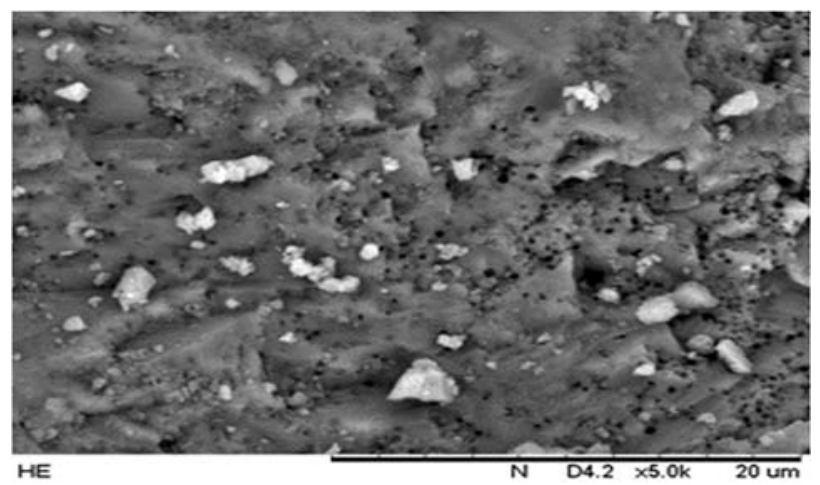

(b)

Fig. 2: SEM micrographs of (a) raw eggshell waste and (b) hybrid eggshell-pandan biosorbents.

As observed, the raw eggshell powdered particles have irregular crystalline structure and a wide particle size range was observed. Both adsorbents are proved to have small interspace structure which provide large surface area for adsorption. While for the micrographs of the hybrid eggshell-pandan sorbent, obviously there are many small compound attached on the eggshell surface. This had proven the successful impregnation process of 2-AP compound onto the eggshell surface.

\subsubsection{BET analysis}

The surface area of the raw eggshell and hybrid eggshell-pandan sorbent are determined to be $1.61 \mathrm{~m}^{2} / \mathrm{g}$ and $0.46 \mathrm{~m}^{2} / \mathrm{g}$. This surface area of raw eggshell is almost similar to that of $1.05 \mathrm{~m}^{2} / \mathrm{g}$ of eggshell ${ }^{15)}$. The decrement in specific surface area of the hybrid sorbent compared to the raw eggshell powder might attributed to the covering of the pores by 2 -AP compounds.

\subsection{Adsorption study}

\subsubsection{Effect of reaction time on $\mathrm{Cr}$ (VI) removal}

Fig. 3 shows the effect of reaction on the biosorption of $\mathrm{Cr}$ (VI) ion by plotting the percentage removal of $\mathrm{Cr}$ (VI) ions versus the reaction time. The interval of the reaction time when concentration of chromium ion was measured is $20 \mathrm{~min}$.

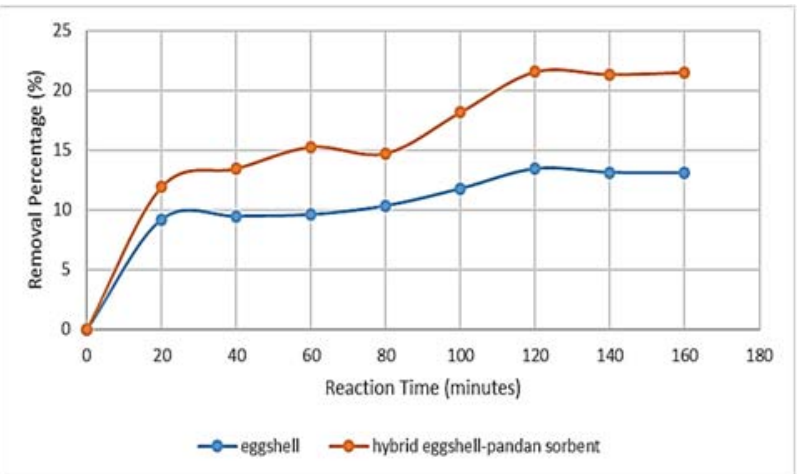

Fig. 3: Effect of reaction time.

By comparing both curves with different types of biosorbent, hybrid eggshell-pandan sorbent shows greater removal percentage of $\mathrm{Cr}(\mathrm{VI})$ ion $(21.51 \%)$ than raw eggshell sorbent (13.12\%). Both biosorbents show a relatively great removal percentage of chromium ion at the beginning of removal process due to the highly available binding sites on the surface of sorbent. Then, the rate of adsorption gradually decreases with increasing reaction time as the gradient of the curve decrease. As the adsorption process goes on, the biosorbent surfaces are highly saturated, the diffusion of metal ions into the inner part of biosorbent and thus lower down the rate of adsorption $^{14)}$. From the result, an equilibrium time of 140 minutes is sufficient to obtain the maximum $\mathrm{Cr}$ (VI) ions removal percentage. Thus, the equilibrium time of 140 min was used for the further studies on biosorption of raw eggshell and hybrid eggshell-pandan sorbent. 


\subsubsection{Effect of biosorbent dosage on Cr (VI) removal}

The effect of raw eggshell and hybrid sorbent dosage, ranging from 0.1 to $1 \mathrm{~g}$ was studied for a contact time of 140 minutes. Fig. 4 indicates the similar trend for both biosorbent, where the $\mathrm{Cr}$ (VI) ions removal percentage increases as the dosage increase from $0.1 \mathrm{~g}$ to $0.5 \mathrm{~g}$ and reaches the maximum removal percentage at $0.5 \mathrm{~g}$ of biosorbent. The maximum removal percentage of $\mathrm{Cr}$ (VI) ions by $0.5 \mathrm{~g}$ of eggshell and hybrid sorbent are $17.9 \%$ and $26 \%$ respectively. the higher the biosorbent dosage, the greater the adsorbent surface areas, and thus augmenting the number of available adsorptions sites ${ }^{17}$.

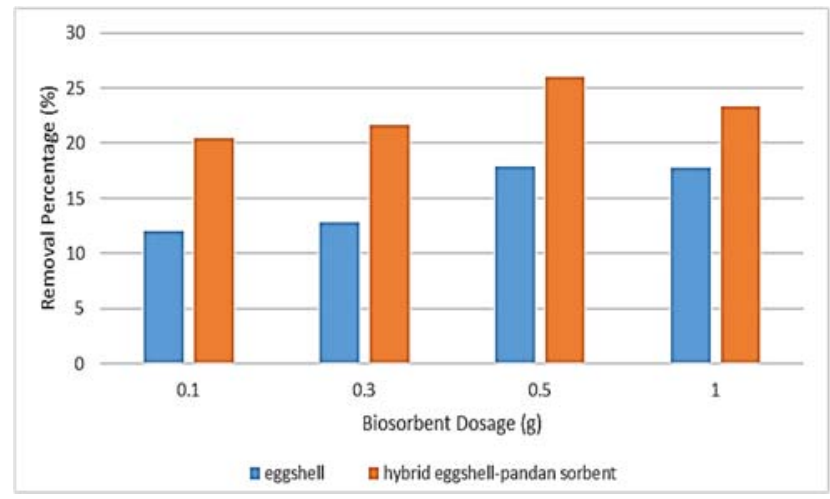

Fig. 4: Effect of biosorbent dosage.

The further increase of biosorbent dosage greater than $0.5 \mathrm{~g}$ lower the removal efficiency of $\mathrm{Cr}$ (VI) ions. This result fits with the theory because it reaches the equilibrium between chromium ions and the biosorbent ${ }^{17}$. The further increase over the optimum dosage will lead to screen effect between the sorbent particles. $0.5 \mathrm{~g}$ of biosorbent of raw eggshell and hybrid eggshell-pandan are used as the optimum dosage for the following sets of adsorption study.

\subsubsection{Effect of temperature on $\mathrm{Cr}(\mathrm{VI})$ removal}

From Fig. 5, it illustrates that raw eggshell has the highest removal efficiency at $25^{\circ} \mathrm{C}$ while hybrid eggshellpandan sorbent exhibits greatest removal capability at $50{ }^{\circ} \mathrm{C}$. As expected, the hybrid eggshell-pandan sorbent shows higher $\mathrm{Cr}$ (VI) ions removal percentage than raw eggshell.

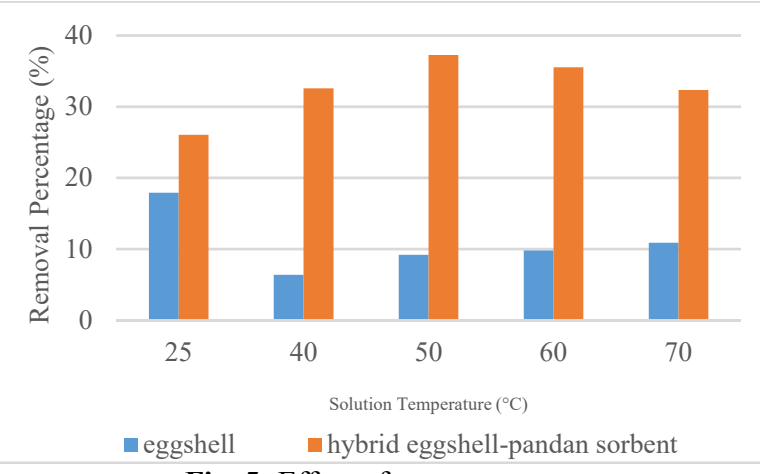

Fig. 5: Effect of temperature.
For the hybrid eggshell-pandan sorbent, the removal percentage shows an increasing trend when temperature increases from $25{ }^{\circ} \mathrm{C}$ to $50{ }^{\circ} \mathrm{C}$. The removal efficiency reaches the optimum at $50{ }^{\circ} \mathrm{C}$ with the $\mathrm{Cr}$ (VI) ions removal percentage of $37.3 \%$. Surface activity and kinetic energy of the adsorbent increase, more metal ions are able to diffuse into the biosorbent and thus increase the adsorption ability of the sorbent ${ }^{11)}$. Further increase in temperature after $50^{\circ} \mathrm{C}$ leads to slightly lower removal efficiency. This might due to the damage of the physical structure of biosorbent, in this case the denaturation of protein $^{18,19)}$.

For raw eggshell sorbent, the removal percentage decrease from $17.9 \%$ to $6.4 \%$ during the temperature increase from $25^{\circ} \mathrm{C}$ to $40^{\circ} \mathrm{C}$. This significant decrease due to denaturation of the biosorbent at high temperature starting from $40{ }^{\circ} \mathrm{C}$. However, the removal efficiency increase very slightly when temperature increase from $40{ }^{\circ} \mathrm{C}$ to $70{ }^{\circ} \mathrm{C}$. This slight increment in percentage is due to the driving force of the increasing kinetic energy is greater than the effect of biosorbent denaturation. Thus, $50^{\circ} \mathrm{C}$ and $25^{\circ} \mathrm{C}$ is taken as the optimum temperature for raw eggshell and hybrid sorbent respectively.

\subsubsection{Effect of pH on $\mathrm{Cr}$ (VI) removal}

The effect of $\mathrm{pH}$ on the $\mathrm{Cr}$ (VI) ions adsorption is investigated over a range from $\mathrm{pH} 4$ to $\mathrm{pH} 8$ for both raw eggshell and hybrid eggshell-pandan sorbent. The results indicated that the $\mathrm{Cr}$ (VI) ions adsorption capacity is doubled up from $16.8 \%$ to $37 \%$, after the eggshell was modified by hybridisation with pandan solution.

As showed in Fig. 6, the maximum adsorption percentage for hybrid eggshell-pandan sorbent is observed at $\mathrm{pH} 4$ and the trend is similar to the study of Liu and Huang $(2011)^{20)}$. The removal capacity starts to decrease sharply when $\mathrm{pH}$ value is increased from the optimum value to $\mathrm{pH} 8$. However, for raw eggshell sorbent, the highest $\mathrm{Cr}$ (VI) ions adsorption is determined when the adsorption process is conducted at $\mathrm{pH} 5^{21}$.

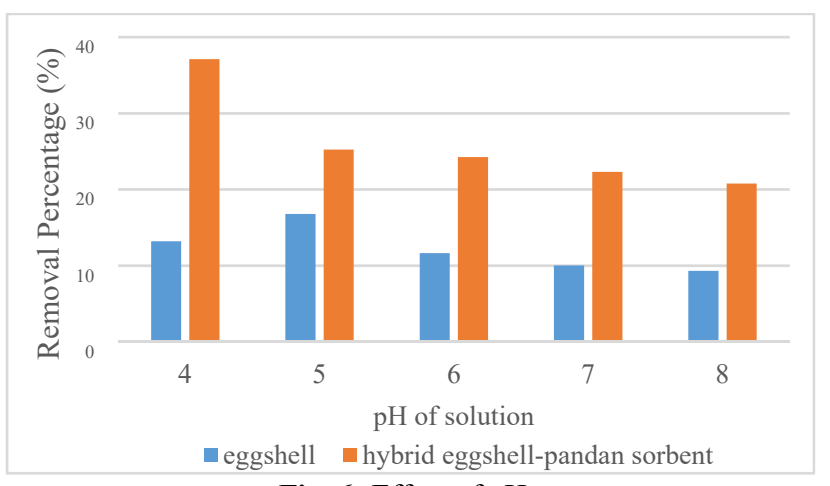

Fig. 6: Effect of $\mathrm{pH}$.

Under acidic solution, the $\mathrm{H}^{+}$ions protonated the amino groups and positively charged active sites present. 
This positive charge active site will form an electrostatic attraction with $\mathrm{Cr}(\mathrm{VI})$ anions, $\mathrm{HCrO}_{4}^{-}$. When the $\mathrm{pH}$ value of the solution increase, concentration of $\mathrm{H}^{+}$ decrease but the concentration of $\mathrm{OH}^{-}$increase. $\mathrm{OH}^{-}$will compete with chromium anion and thus lower the removal percentage $^{22)}$.

\subsubsection{Effect of initial ion concentration on $\operatorname{Cr}(\mathrm{VI})$ removal}

Fig. 7 clearly illustrated that the removal percentage of $\mathrm{Cr}$ (VI) ions decreased from $17.78 \%$ to $8.23 \%$ for raw eggshell sorbent and from $37.88 \%$ to $16.1 \%$ for hybrid eggshell-pandan sorbent. Both types of sorbent had the same range of increase in the value of the initial concentration of $\mathrm{Cr}$ (VI) ions. This is due to the sufficient number of active sites for adsorption to occur at lower initial concentration, but more metal ions are left unadsorbed in the solution because most of the active sites are occupied at higher initial concentration ${ }^{23)}$.

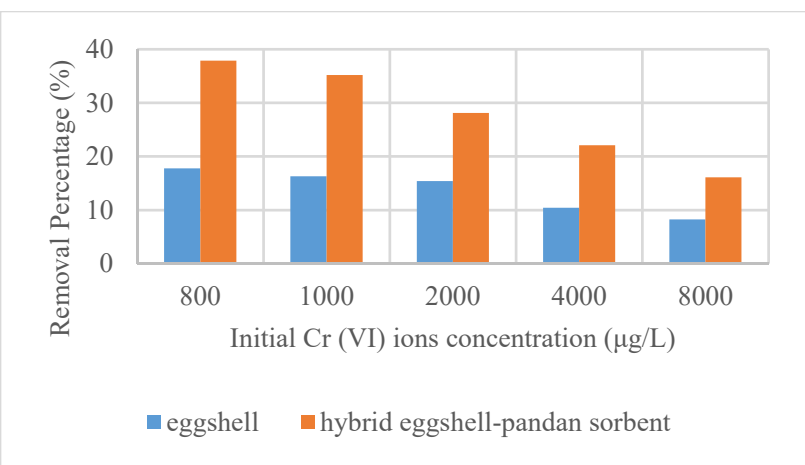

Fig. 7: Effect of initial ion concentration.

Despite of the decreasing removal percentage of $\mathrm{Cr}$ (VI) ions in the solution, the adsorption capacity of the biosorbent, which are raw eggshell and hybrid sorbent increase. The higher the initial metal ions concentration, the greater the driving force to overcome the mass transfer resistance ${ }^{24)}$. Thus, the removal capacity of the adsorbent increase.

\subsection{Kinetic study}

The adsorption data of $\mathrm{Cr}$ (VI) ions using hybrid eggshell-pandan biosorbent is analysed using pseudo firstorder, pseudo second-order kinetics models and intraparticles diffusion model.

Legergren pseudo first-order model proposed that the surface of sorbent which initially has no analytes on it will have metal ions accumulated over its surface as time progresses. The rate constant, $\mathrm{K}_{1}$ and the equilibrium amount of $\mathrm{Cr}$ (VI) ion adsorbed can be obtained from the slope and the $y$-interception of the plot between $\ln \left(\mathrm{q}_{\mathrm{e}}-\mathrm{q}_{\mathrm{t}}\right)$ versus time, $\mathrm{t}$ as shown in Fig. 8 respectively. The calculated data is tabulated in Table 1 . The results prove that pseudo-first-order model does not fit well for the whole range of the reaction time. This is because the surface of the hybrid eggshell-pandan sorbent is not homogenous.

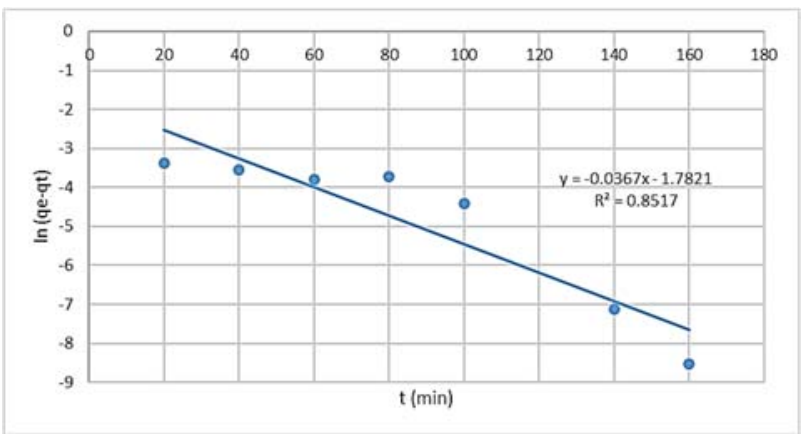

Fig. 8: Pseudo-first-order kinetic model.

Similar to the first order, the value of $\mathrm{K}_{2}$ and qe of pseudo-second-order kinetic model can be obtained from the slope and intercept of the plot $\mathrm{t} / \mathrm{qt}$ versus time respectively. The graph showed in Fig. 9 and the data is tabulated in Table 1. This figure represents relatively good fit over the whole range of contact time. This suggest that the biosorption may be the rate-limiting step that involve valence forces through sharing or exchange of electrons between sorbent and sorbate, which regards to chemisorption $^{25)}$.

By comparing the $\mathrm{R}^{2}$ value of the first order and second order, it is obvious that the ongoing adsorption of $\mathrm{Cr}$ (VI) ions follows pseudo-second-order rate kinetics. Also, compare with that of first order, the $\mathrm{q}_{\mathrm{e}}$ calculated from the graph of pseudo-second-order is closer to experimental value of $\mathrm{q}_{\mathrm{e}}$.

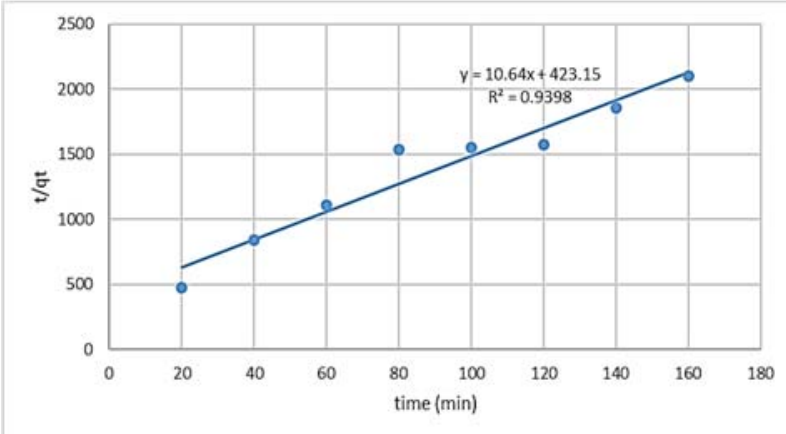

Fig. 9: Pseudo-second-order kinetic model.

Intraparticle diffusion model is also applied to determine the biosorption of $\mathrm{Cr}$ (VI) ions onto hybrid eggshell-pandan sorbent is either a sole intraprticle diffusion rate-determining step or a multi-step process. A graph of qt correlates with values of $t^{1 / 2}$ is drawn as in Fig. 10. The rate constant, $\mathrm{K}_{\text {diff }}$ is directly determined from the slope of the second portion of the straight line and the value of intercept $\mathrm{C}$ indicates the thickness of the boundary layer that resists to external mass transfer. 


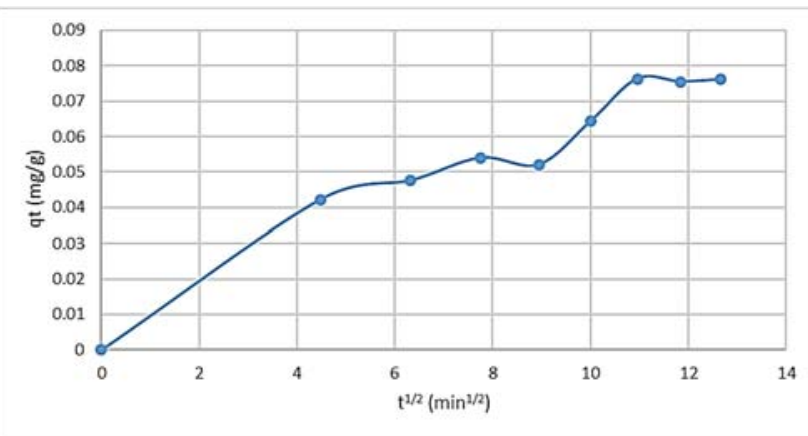

Fig. 10: Intraparticle diffusion kinetic model.

The adsorption of $\mathrm{Cr}$ (VI) onto hybrid sorbent is a mutli-step process into the interior of sorbent as the plot shows three intersecting lines. The first stage is the first sharper portion as the rapid external surface adsorption, the second linear portion with gradual adsorption as intraparticle diffusion and the final portion as the final equilibrium stage. The intraparticle diffusion step is the rate limiting factor and the final step came to equilibrium due to the very low metal ion concentration in solution phase and the limited available sorption sites on the biosorbent ${ }^{12)}$. The kinetic parameters also tabulated in Table 1.

\subsection{Isotherm studies}

The Langmuir, Freundlich and Temkin adsorption isotherm models were used to analyse the adsorption mechanism of $\mathrm{Cr}$ (VI) ions onto the hybrid eggshellpandan sorbent surface. Fig. 11 shows the straight line plot for Langmuir adsorption isotherm model for $\mathrm{Cr}$ (VI) ions onto hybrid sorbent. Langmuir isotherm model is based on the assumption of there are a finite number of active sites which are homogeneously distributed over the surface of the adsorbent ${ }^{26)}$.

All the calculated parameter values are tabulated as in Table 2. All the $\mathrm{R}_{\mathrm{L}}$ values lie between 0.3 and 0.8 for the initial chromium (VI) concentration range from $0.8 \mathrm{mg} / \mathrm{L}$ to $8 \mathrm{mg} / \mathrm{L}$. This indicated that the adsorption is favourable as the values were in between 0 and $1^{27)}$.

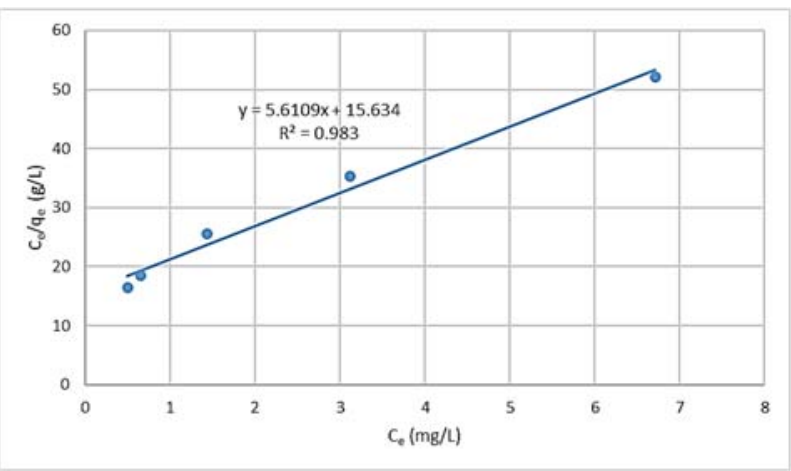

Fig. 11: Langmuir isotherm.

For Freundlich isotherm model assumed multilayer adsorption and is applicable to highly heterogeneous surface. It assumed that there are interactions between the adsorbed molecules and formation of monolayer is not restricted. The linear graph plotted $\ln \mathrm{q}_{\mathrm{e}}$ versus $\ln \mathrm{C}_{\mathrm{e}}$ is shown in Fig. 12. The $\mathrm{n}$ value also suggested a same magnitude of retention of $\mathrm{Cr}(\mathrm{VI})$ ions from solution take place by ionic interactions initially ${ }^{13)}$. From the interception of $y$-axis, the maximum adsorption capacity obtained is $0.0453 \mathrm{mg} / \mathrm{g}$. When the metal ion concentration increases, the concentration of the adsorbate on the sorbent surface also increases ${ }^{25}$.

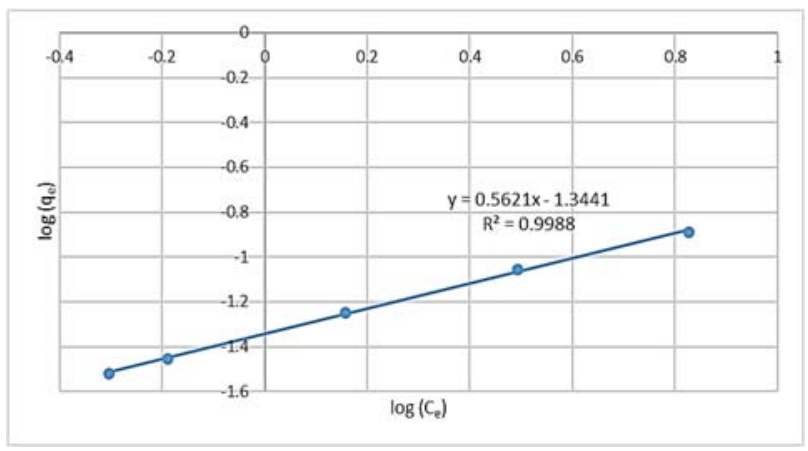

Fig. 12: Freundlich isotherm.

Temkin isotherm derived from the assumptions of a heterogeneous surface energy systems where the distribution of heat is non-uniform. The slope of the graph $\mathrm{q}_{\mathrm{e}}$ versus $\ln \mathrm{C}_{\mathrm{e}}$ illustrated in Fig. 13 represented the value of constant related to heat of sorption, $\mathrm{B}$. The $\mathrm{B}$ value indicated that the biosorption process happened in both chemisorption and physisorption ${ }^{13)}$.

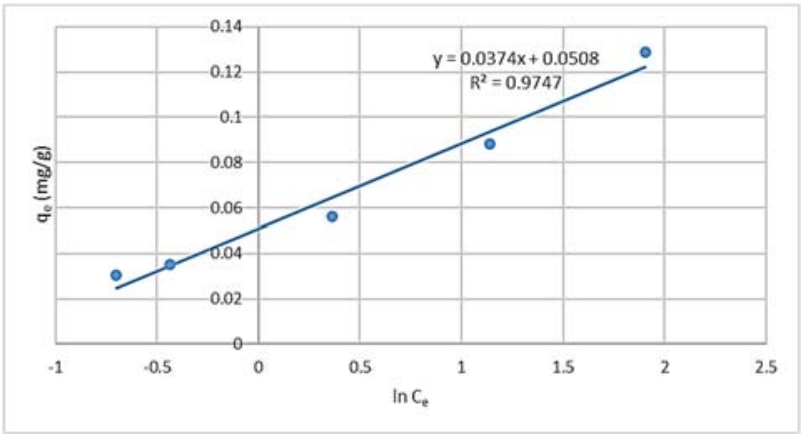

Fig. 13: Temkin isotherm.

All the parameters calculated from each isotherm models were tabulated as in Table 2. From the table, the value of $\mathrm{R}^{2}$ showed that the experimental data were best fitted to Freundlich isotherm model compared to that of Langmuir and Temkin isotherm with the value 0.9988, 0.9830 and 0.9747 respectively. This suggests that the adsorption of chromium (VI) ions onto the hybrid eggshell-pandan biosorbent may due to multilayer adsorption. The surface of hybrid sorbent is proven to be heterogeneous surface, similar to the result in the adsorption kinetic studies. There are interactions between molecules attached onto the sorbent surface.

\subsection{Thermodynamic study}

To investigate the thermodynamic behavior of the adsorption of chromium (VI) ions onto the hybrid eggshell-pandan biosorbent, the thermodynamic 
parameters such as change in Gibbs free energy $\left(\Delta \mathrm{G}^{\circ}\right)$, change in enthalpy $\left(\Delta \mathrm{H}^{\circ}\right)$ and change in entropy $\left(\Delta \mathrm{S}^{\circ}\right)$ are determined. Through this, it can be determined whether the adsorption is exothermic or endothermic, and spontaneous or not. A graph of ln kd versus $1 / \mathrm{T}$ was plotted as in Fig. 14. The parameter changes in enthalpy and change in entropy can be determined from the gradient and the intercept of the linear plot.

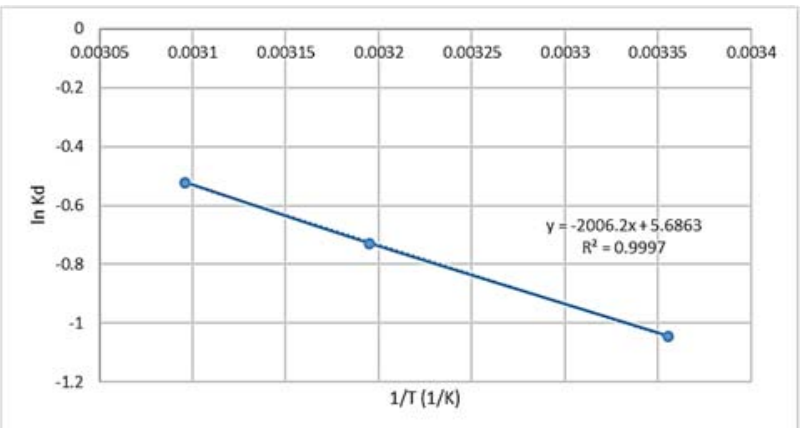

Fig. 14: Thermodynamic study.

The calculated thermodynamic parameters are tabulated in Table 3. The Gibbs free energy values are all in negative. This indicated that the adsorption of $\mathrm{Cr}$ (VI) ions onto the hybrid eggshell-pandan sorbent is spontaneous and feasible throughout the experiment. Moreover, the positive value of the change in enthalpy implies that the adsorption process of $\mathrm{Cr}$ (VI) ions onto hybrid sorbent is endothermic and hence the process is more suitable to carry out in relatively higher temperature. While the positive value of the $\Delta \mathrm{S}^{\circ}$ showed that the randomness at the solid solution interface increase ${ }^{21)}$.

Table 1. Kinetic parameters.

\begin{tabular}{|c|c|c|c|c|c|c|c|c|}
\hline \multicolumn{3}{|c|}{ Pseudo-first-order } & \multicolumn{3}{|c|}{ Pseudo-second-order } & \multicolumn{2}{|c|}{ Intraparticle diffusion } & \multirow{2}{*}{$\begin{array}{c}\mathrm{q}_{\mathrm{e}, \exp } \\
(\mathrm{mg} / \mathrm{g})\end{array}$} \\
\hline $\begin{array}{c}\mathrm{q}_{\mathrm{e}, \mathrm{cal}} \\
(\mathrm{mg} / \mathrm{g})\end{array}$ & $\begin{array}{c}\mathrm{K}_{1} \\
\left(\min ^{-1}\right)\end{array}$ & $\mathrm{R}^{2}$ & $\begin{array}{c}\mathrm{q}_{\mathrm{e}, \mathrm{cal}} \\
(\mathrm{mg} / \mathrm{g})\end{array}$ & $\begin{array}{c}\mathrm{K}_{2} \\
(\mathrm{~g} / \mathrm{mgmin})\end{array}$ & $\mathrm{R}^{2}$ & $\begin{array}{c}\mathrm{K}_{\text {diff }} \\
\left(\mathrm{mg} \mathrm{g}^{-1} \min ^{-1 / 2}\right)\end{array}$ & $\mathrm{R}^{2}$ & \\
\hline 0.1683 & 0.0367 & 0.8517 & 0.0940 & 0.2675 & 0.9398 & 0.0047 & 0.9067 & 0.0763 \\
\hline
\end{tabular}

Table 2 The Langmuir, Freudlich and Temkin parameters for the adsorption of $\mathrm{Cr}$ (VI) onto hybrid sorbent.

\begin{tabular}{|c|c|c|}
\hline \multirow{4}{*}{ Langmuir Isotherm } & $\mathrm{b}(\mathrm{L} / \mathrm{mg})$ & 0.4189 \\
\cline { 2 - 3 } & $\mathrm{q}_{\mathrm{m}}(\mathrm{mg} / \mathrm{g})$ & 0.1712 \\
\cline { 2 - 3 } & $\mathrm{R}_{\mathrm{L}}$ & $0.7490-0.2298$ \\
\cline { 2 - 3 } & $\mathrm{R}^{2}$ & 0.9830 \\
\hline \multirow{3}{*}{ Freundlich Isotherm } & $\mathrm{K}_{\mathrm{F}}\left[(\mathrm{mg} / \mathrm{g})(\mathrm{L} / \mathrm{mg})^{(1 / \mathrm{n})}\right]$ & 0.0453 \\
\cline { 2 - 3 } & $\mathrm{n}(\mathrm{g} / \mathrm{L})$ & 1.7790 \\
\cline { 2 - 3 } & $\mathrm{R}^{2}$ & 0.9988 \\
\hline \multirow{3}{*}{ Temkin Isotherm } & $\mathrm{B}(\mathrm{J} / \mathrm{mol})$ & 0.0374 \\
\cline { 2 - 3 } & $\mathrm{A}(\mathrm{L} / \mathrm{g})$ & 3.8895 \\
\cline { 2 - 3 } & $\mathrm{R}^{2}$ & 0.9747 \\
\hline
\end{tabular}

Table 3 Thermodynamic parameters for $\mathrm{Cr}$ (VI) ions adsorption onto hybrid eggshell-pandan sorbent.

\begin{tabular}{|c|c|c|c|}
\hline $1 / \mathrm{T}\left(\mathrm{K}^{-1}\right)$ & $\Delta \mathrm{G}^{\circ}(\mathrm{KJ} / \mathrm{mol})$ & $\Delta \mathrm{H}^{\circ}(\mathrm{KJ} / \mathrm{mol})$ & $\Delta \mathrm{S}^{\circ}(\mathrm{KJ} / \mathrm{mol})$ \\
\hline 0.0034 & -2.5861 & \multirow{2}{*}{0.6796} & 0.0473 \\
\hline 0.0032 & -1.8954 & & \\
\hline 0.0031 & -1.4005 & & \\
\hline
\end{tabular}

\section{Conclusion}

Hybrid eggshell-pandan biosorbent was successfully synthesised in this study. Characterization of raw eggshell waste and hybrid biosorbent using FTIR proved the presence of $\mathrm{O}-\mathrm{H}$ and $\mathrm{N}-\mathrm{H}$ functional groups is important for the adsorption reaction. The SEM micrographs also indicated the attachment of 2-AP compounds onto the eggshell surface. BET analysis showed decrement of specific surface area of the hybrid sorbent compared to the raw eggshell sorbent. The optimum conditions for the adsorption of $\mathrm{Cr}$ (VI) ions onto raw eggshell waste were 140 min contact time, $0.5 \mathrm{~g}$ dosage of biosorbent, $25^{\circ} \mathrm{C}$ 
and $\mathrm{pH} 5$ of metal ions solution. Whereas for hybrid eggshell-pandan biosorbent, the removal efficiency was optimum when the contact time is $140 \mathrm{~min}$ and the dosage of hybrid biosorbent is $0.5 \mathrm{~g}$ which were similar as the raw eggshell sorbent. However, removal efficiency was higher when the temperature is at $50{ }^{\circ} \mathrm{C}$ and $\mathrm{pH} 4$. Both type of biosorbent reach optimum efficiency at relatively low temperature and acidic condition, which proved them to be suitable being applied in industry operations. Both biosorbent showed higher removal capacity but lower removal percentage at $0.8 \mathrm{mg} / \mathrm{L}$ of solution. Hybrid biosorbent proved to be a better biosorbent as it had higher removal percentage than raw eggshell in every parameter tested. The adsorption kinetic study indicated that the adsorption follows pseudo-second-order of Lagergren kinetic model with $0.94 \mathrm{R}^{2}$ value. Similar to the kinetic study, Freundlich isotherm model which best fit with the experiment data proved the surface of the hybrid biosorbent is heterogeneous. Biosorption of $\mathrm{Cr}(\mathrm{VI})$ ions by hybrid eggshell-pandan biosorbent was spontaneous, feasible and endothermic process. In short, hybrid eggshell-pandan is highly potential and marketable biosorbent.

\section{Acknowledgement}

This study was supported by Universiti Malaysia Pahang and Universiti Teknologi Malaysia under UMP Research Grant Scheme vot no. RDU1803167.

\section{References}

1) M.A.A. Wahid, M.J.M.M. Noor and H. Hara, "Recombinant moringa oleifera lectin produced in pichia pastoris is a potential natural coagulant," Evergreen. 3 (2), 11-16 (2016). doi.org/10.5109/1800867.

2) D. Yu, W. Lili, and W. Minghua, "Simultaneous removal of dye and heavy metal by banana peels derived hierarchically porous carbons," Journal of the Taiwan Institute of Chemical Engineers, 93, 543-553 (2018). doi.org/10.1016/j.jtice.2018.08.038.

3) M. Yusei, "Characteristics of industrial wastewater discharged from industrialized provinces and specific industrial sectors in china based on the official statistical reports," Evergreen. 3 (2), 59-67 (2016).

4) M.W. Shahzad, K. Thu, B.B. Saha and K.C. Ng. "An emerging hybrid multi-effect adsorption desalination system," Evergreen. 1 (2), 30-36 (2014). doi.org/10.5109/1495161.

5) M.K. Marichelvam, and A. Azhagurajan, "Removal of mercury from effluent solution by using banana corm and neem leaves activated charcoal," Environmental Nanotechnology, Monitoring \& Management, 10, 360-365 (2018). doi.org/10.1016/j.enmm.2018.08.005.

6) H.N. Bhatti, A. W. Nasir, and M.A. Hanif, "Efficacy of Daucus carota L. waste biomass for the removal of chromium from aqueous solutions," Desalination, 253 (1-3), 78-87 (2010). doi.org/10.1016/j.desal.2009.11.029.

7) M. Lutfiyatul and R. Barlah. "Modification of Biochitin Immobilized Dithizone as adsorbent for $\mathrm{Cr}$ (VI) removal," Evergreen. 7 (3), 429-435 (2020). doi.org/10.5109/4068623.

8) D. Chen, X. Xiao, and K. Yang, "Removal of phosphate and hexavalent chromium from aqueous solutions by engineered waste eggshell," RSC Advances, 6 (42), 35332-35339 (2016). doi.org/10.1039/C6RA05034D.

9) J.R.Chambers, K. Zaheer, H. Akhtar, E-S. M. AbdelAal. "Chapter 1- Chicken Eggs," Egg innovations and strategies for improvements. 1-9 (2017). doi.org/10.1016/B978-0-12-800879-9.00001-9.

10) M. El Haddad, R. Slimani, R. Mamouni, M.R. Laamari, S. Rafqah, and S. Lazar, S. "Evaluation of potential capability of calcined bones on the biosorption removal efficiency of safranin as cationic dye from aqueous solutions," Journal of the Taiwan Institute of Chemical Engineers, 44 (1), 13-18 (2013). doi.org/10.1016/j.jtice.2012.10.003.

11) Q. Qin, J. Ma, and K. Liu, "Adsorption of anionic dyes on ammonium-functionalized MCM-41," Journal of Hazardous Materials, 162 (1), 133-139 (2009). doi.org/10.1016/j.jhazmat.2008.05.016.

12) A. Adamczuk, and D. Kołodyńska, "Equilibrium, thermodynamic and kinetic studies on removal of chromium, copper, zinc and arsenic from aqueous solutions onto fly ash coated by chitosan," Chemical Engineering Journal, 274, 200-212 (2015). doi.org/10.1016/j.cej.2015.03.088.

13) M. Erhayem, F. Al-Tohami, R. Mohamed, and K. Ahmida, "Isotherm, Kinetic and Thermodynamic Studies for the Sorption of Mercury (II) onto Activated Carbon from Rosmarinus officinalis Leaves," American Journal of Analytical Chemistry, 6 (1), 1-10 (2015). doi.org/ 10.4236/ajac.2015.61001.

14) Z.T.A. Ali, M.A. Ibrahim, H.M. and Madhloom, "Eggshell powder as an adsorbent for removal of $\mathrm{Cu}(\mathrm{II})$ and $\mathrm{Cd}(\mathrm{II})$ from aqueous solution: Equilibrium, kinetic and thermodynamic studies," Al-Nahrain University, College of Engineering Journal, 19 (2), 186-193 (2016).

15) P.S. Guru, and S. Dash, "Amino Acid Modified Eggshell Powder (AA-ESP)-A Novel Bio-Solid Scaffold for Adsorption of Some Styrylpyridinium Dyes" Journal of Dispersion Science and Technology, 34 (8), 1099-1112 (2013). doi.org/10.1080/01932691.2012.737752.

16) J. Carvalho, A. Ribeiro, J. Araujo, and F. Castro, "Technical Aspects of Adsorption Process onto an Innovative Eggshell-Derived Low-Cost Adsorbent," Material Science Forum, 730-732, 648-652 (2013). doi.org/10.4028/www.scientific.net/MSF.730732.648 . 
17) S. Elabbas, L. Mandi, F. Berrekhis, M.N. Pons, J.P. Leclerc, and N. Ouazzani, "Removal of Cr(III) from chrome tanning wastewater by adsorption using two natural carbonaceous materials: Eggshell and powdered marble," Journal of Environment Management, 166, 589-595 (2016).

doi.org/10.1016/j.jenvman.2015.11.012.

18) K. Chojnacka, "Biosorption of $\mathrm{Cr}$ (III) ions by eggshells," Journal of Hazardous Materials, 121 (13), 167-173 (2005).

doi.org/10.1016/j.jhazmat.2005.02.004.

19) A.F. Ridassepri, R. Fitria, K.R. Heliani, Chairunnisa. "Activated carbon from bagasse and its application for water vapor adsorption," Evergreen. 7 (3), 409416 (2020).

20) A. Mittal, M. Teotia, R.K. Soni, J. Mittal, "Applications of egg shell and egg shell membrane as adsorbents: A review," Journal of Molecular Liquids, 223, 376-387 (2016).

doi.org/10.1016/j.molliq.2016.08.065.

21) H. Daraei, A. Mittal, M. Noorisepehr, and J. Mittal, "Separation of chromium from water samples using eggshell powder as a low-cost sorbent: kinetic and thermodynamic studies," Desalination and Water Treatment, 53 (1), 214-220 (2013). doi.org/10.1080/19443994.2013.837011.

22) B. Liu, and Y. Huang, "Polyethyleneimine modified eggshell membrane as a novel biosorbent for adsorption and detoxification of $\mathrm{Cr}(\mathrm{VI})$ from water," Journal of Materials Chemistry, 21 (43), 1741317418 (2011). doi.org/10.1039/C1JM12329G.

23) T.K. Naiya, A. K. Bhattacharya, S. Mandal, and S.K. Das, "The sorption of lead(II) ions on rice husk ash," Journal of Hazardous Materials, 163 (2-3), 12541264 (2009).

doi.org/10.1016/j.jhazmat.2008.07.119.

24) H. Pahlavanzadeh, A.R. Keshtkar, J. Safdari, and Z. Abadi, "Biosorption of nickel(II) from aqueous solution by brown algae: equilibrium, dynamic and thermodynamic studies," Journal of Hazardous Materials, $175 \quad$ (1-3), 304-310 (2010). doi.org/10.1016/j.jhazmat.2009.10.004.

25) N. Fiol, I. Villaescusa, M. Martínez, N. Miralles, J. Poch, and J. Serarols, "Sorption of $\mathrm{Pb}(\mathrm{II}), \mathrm{Ni}(\mathrm{II})$, $\mathrm{Cu}$ (II) and $\mathrm{Cd}(\mathrm{II})$ from aqueous solution by olive stone waste," Separation and Purification Technology, $\quad 50 \quad$ (1), $132-140 \quad$ (2006). doi.org/10.1016/j.seppur.2005.11.016.

26) G. Vijayakumar, R. Tamilarasan, and M. Dharmendirakumar, "Adsorption, Kinetic, Equilibrium and Thermodynamic studies on the removal of basic dye Rhodamine-B from aqueous solution by the use of natural adsorbent perlite," Journal of Materials Environment Sciences, 3 (1), 157-170 (2012).

27) W. S. Wan Ngah, and M. A. K. M. Hanafiah, "Adsorption of copper on rubber (Hevea brasiliensis) leaf powder: Kinetic, equilibrium and thermodynamic studies," Biochemical Engineering $\begin{array}{llll}\text { Journal, } & 39 & \text { (3), } & 521-530 \quad \text { (2008). }\end{array}$ doi.org/10.1016/j.bej.2007.11.006. 